\title{
iCircassia: Digital Capitalism and New Transnational Identities
}

\section{Lars Funch Hansen ${ }^{*}$}

\begin{abstract}
The significantly increased production of Circassian content on the Internet could be labelled as a form of virtual re-territorialisation of Circassia - especially considering the strong focus on identity and history. I apply the label 'iCircassia' as an addition to the classical understanding of the Circassian World as consisting of Circassians of the homeland and the diaspora. I suggest to apply the term 'digital capitalism' as an update of the terms 'print capitalism' and 'electronic capitalism' used by Benedict Anderson and Arjun Appadurai, respectively, to assign earlier periods of mediated mobilisation among nationalities - with or without a nation-state. In the case of the Circassians this is not just exemplified by the many different Circassian websites but also by the Circassians' use of social media such as YouTube, Facebook and Twitter (Web 2. 0) - transnational and (partly) interactive by definition. A concrete empowerment of Circassian actors through the Internet is taking place. This illustrated how the development of 'digital capitalism' has both quantitatively and qualitatively new implications for a dispersed people such as the Circassians compared to earlier periods.
\end{abstract}

Keywords: 'Digital Capitalism', Internet, 'Transnational Identitybuilding', Globalisation, Empowerment.

\section{E-Çerkesya: Dijital Kapitalizm ve Yeni Ulusaşırı Kimlikler}

\section{Özet}

Başta ulusal kimlik ve tarih konularına odaklananlar olmak üzere, internette sayısı giderek artan Çerkeslerle ilgili materyaller, bir anlamda siber alemde Çerkesya'nın sınırlarının yeniden çizilmesi

* Dr. Lars Funch Hansen, Lecturer at Caucasus Studies at Malmö University, Sweden. 
olarak da değerlendirilebilir. Bu makalede 'e-Çerkesya' ('iCircassia') terimini, genel olarak anavatan ve diasporadan oluştuğu kabul edilen klasik Çerkes Dünyası kavramına ek olarak kullanıyorum. 'Dijital Kapitalizm' kavramının, erken dönem milliyetlerde (ulus devleti olsun ya da olmasın) yaşanan mobilizasyonları tanımlamak için Benedict Anderson tarafından üretilen 'matbaa kapitalizmi' ve Arjun Appadurai tarafından üretilen 'elektronik kapitalizm' kavramlarının bir güncellemesi olarak kullanılmasını öneriyorum. Çerkesler özelinde bu durum sadece değişik Çerkes internet sitelerinin varlığıyla değil aynı zamanda Youtube, Facebook ve Twitter gibi tanımları gereği ulusaşırı ve bir ölçüde interaktif olan sosyal medya araçlarının Çerkesler tarafından kullanımıyla da örneklendirilebilir. Çerkes dünyasının aktörleri, internet aracılığıyla giderek güçlenmekteler. Bu durum, 'dijital kapitalizm'in gelişiminin geçmiş dönemleriyle karşılaştırıldığında Çerkesler gibi dağınık yaşayan halklar için hem nicelik hem de nitelik olarak çok ciddi etkileri olduğunu ortaya koymaktadır.

\section{Introduction}

The (almost) wholesale exile of the Circassians from their homeland in 1864 after the final victory of the Russian army resulted in Circassia literally being taken off the map. Nonetheless, countless cartographic representations of Circassia from the preceding centuries exist and have today been digitalised, presented and circulated on the Internet. Circassia has, in this way, little by little begun to come back 'on the map' - at least virtually. And to be 'on the map' is a strong metaphor, which indicates the importance of recognition in the ongoing Circassian revival. ${ }^{1}$

The total number of Circassians is today regarded as being somewhere between three and six million, spread across a number of countries. The largest contingent - perhaps more than two million - resides in Turkey. Other significant diaspora groups are found in Syria, Jordan, Israel, Germany, USA and Canada. Today in the Russian Federation reside between 700,000 and 800,000 Circassians in the three North Caucasian republics of Adygea,

\footnotetext{
${ }^{1}$ Lars Funch Hansen (2014). The Circassian Revival. PhD Thesis, Copenhagen University (unpublished).
} 
Kabardino-Balkaria and Karachay-Cherkessia, with a few small communities on the Black Sea coast of Krasnodar Krai. The names of Adygea, Kabarda and Cherkessia are all the names of Circassian peoples, who constitute the titular nationalities of these republics.

Since the mid-2000s, we have witnessed a strong rise in the number of Circassian websites, initiated by a number of individuals and organisations, with diverse aims - though all are united in the goals of presenting information on Circassian history, culture and identity. In the early part of the 2000s, many of the websites were simplistic projects initiated by various groups and individuals but, today, a large number of well-designed and well-functioning Circassian websites, including social media sites, can be found. This includes a number of websites on broader Caucasian issues. In Turkey, the term Circassian (Çerkes in Turkish) has often been used as a collective term for all (North) Caucasian mountaineers (including, for instance, the Abkhazians). The presence of many new (North) Caucasian websites - and the fact that they often link to each other or recycle each other's texts - have resulted in a 'multiplier effect' of their visibility on the Internet. In this way, the joint sum becomes more than its single parts. This also increases the potential outreach towards relevant target groups - also beyond the Circassians and the Caucasians. The websites on Circassian issues all contribute to the production and reproduction of contemporary Circassian identity. 'iCircassia' - Internet-Circassia - is my term for the joint efforts of the many web-based creations and recreations of an imaginary homeland.

The Internet has spawned a number of new challenges, opportunities and a new terminology for researchers of ethnic identity and nationalism, such as cyber-ethnography, electronic or Internet nations, virtual communities, digital diasporas etc. In this paper, I argue that iCircassia is a virtual transnational ethnocultural space existing on the Internet, which both diaspora Circassians and homeland Circassians actively contribute to. ${ }^{2}$ The websites can roughly be classified into two main groups: A) classic websites providing information and, for instance, functioning as

\footnotetext{
${ }^{2}$ This reflects a new and/or additional way of community building that is not unfolding only in cyberspace.
} 
tools for organisations (often including interactive discussion forums), and B) social web media, such as Facebook, YouTube, Twitter etc. The increased level of hyperlinking has, however, increasingly blurred the boundary between these two forms, in which, for instance, social Internet media increasingly is used as different or additional tools of communication by civil society organisations.

In many ways, 'iCircassia' is an 'imagined community' in the same sense as the nation-states analysed by Benedict Anderson in his 1983 book of the same name, where he employed the term 'print capitalism' to designate the way nation-states increasingly became institutionalised through the production, distribution and general utilization of printed representations from the nineteenth century. Similar processes of nation-building or ethnicity-building efforts have, however, unfolded among most of the ethnic groups found in the North Caucasus, through shifting phases and conditions over the last two hundred years. This is, nonetheless, generally with a greater degree of civil society actor involvement as compared to the official nationalism of nation-states (Anderson $1983 / 1991,163) .^{3}$ In the 1990s, the term 'print capitalism' was updated and elaborated by Arjun Appadurai and others to become the term 'electronic capitalism', which I use as a platform for discussing the recent developments among the Circassian websites. To further update the term into 'digital capitalism', I suggest distinguishing it from the former phase, which largely focused on the role of television and radio.

\section{From Print to Digital Capitalism}

The inspiration for this section is drawn mainly from two analytical terms applied to examine significant changes in communication technologies. Firstly, the shift from the two former phases of 'print capitalism' and 'electronic capitalism', the two terms developed and/or discussed by Benedict Anderson (1983/1991) and Arjun Appadurai (1996), to the contemporary phase of 'digital

${ }^{3}$ In the Circassian republics in the North Caucasus, a secondary level of official nationalism unfolded during the Soviet period, and especially after 1991, albeit subject to a number of restrictions. 
capitalism'. I have chosen to use the term digital capitalism due to the thematic relevance in continuing the two related abovementioned terms, which are well-established in academic analyses. The contemporary 'digital' phase could also be labelled 'digital mediation' or 'digital publishing'. I argue that this shift is reflected in the shift from the first post-Soviet Circassian revival (CR1) to the post-2005 contemporary Circassian revival (CR2). Secondly, the V.E.R.A.city loop model developed by Maximillian Forte for the analysis of processes of Internet-generated indigenous revival will be discussed in relation to CR2. According to Forte's model, this process can be characterised as a continuous loop of four issues of visibility, embodiment, recognition and authenticity, which I find relevant in relation to the Circassian context.

In his book 'Imagined Communities' from 1983, Benedict Andersons describes how 'print capitalism' became instrumental in the construction of nationalism in the production of modern nation-states from the nineteenth century on. This relates to the use of printed media as a modern dimension in the development of new public spheres with a new role in societies - initially mostly in European contexts. In the aftermath of the fall of Communism in Eastern Europe and the Soviet Union, the ideas of Anderson gained prominent status in many scholarly analyses. ${ }^{4}$ The processes of 'imagining communities' also takes place on levels other than the new nation-states - as has been illustrated on several occasions in the post-Communist world - for instance by ethnic minority groups that had or still have some form of secondary-level territorialadministrative autonomy often representing a hangover from the Soviet period (Hansen 2003). In several cases, this development has been part of an increased tension and conflicts between - new and often nationalising - nation-state and ethnic minority groups. This sometimes evolved into violent conflicts as seen, for instance, in relation to Kosovo/Serbia, Abkhazia/Georgia and Chechnya/Russia - though they all followed different paths. The process of print capitalism and nation-building - on a secondary sub-national level - also affected many other nationalities in the

\footnotetext{
${ }^{4}$ As was the case with other studies of nationalism.
} 
Caucasus, including the Circassians in the three republics of the region, where they constitute titular nationalities as Kabardians, Cherkess and Adygeans respectively. The fact that Anderson ascribes the introduction of print capitalism - in a modern understanding - to the early phases of nationalism and national movements in the nineteenth century also renders it relevant to discuss in relation to Circassia and the Circassians in the nineteenth century. This is illustrated by the geopolitical competition and many printed representations of the century.

In 1996 Arjun Appadurai (drawing inspiration from others) employed the term 'electronic capitalism' to encompass the changes in media technology - especially the role of television, radio and the initial version of the Internet (Appadurai 1996, 161). ${ }^{5}$ Among the features of electronic capitalism highlighted by Appadurai, the 'aural' and 'visual' elements encompass a strong potential for the emotional engagement of target groups and potentially having a greater outreach towards audiences - though still largely non-digital. Furthermore, specific language skills, as in the case of the written media, are not required. Immediately after the fall of the Soviet Union there was a significant rise in the number of publications on Circassian history and identity in the North Caucasus - including translations of books from the nineteenth century which had never before been published in the Soviet Union or in the preceding Russian Empire, where censorship frequently prohibited this. ${ }^{6}$ Some of these publications included eyewitness accounts that challenged the official history writing that many Circassian actors wished to revise. Many of these publications are now remediated and digitalised for presentation

\footnotetext{
${ }^{5}$ In the 1960s, Marshall McLuhan had already published now famous books, in which he, among others, discussed "mankind leaving a typographic age and entering an electronic one" and in the book 'Understanding Media' he coined the term 'The Global Village' to describe the new age of electronic media (Turner 2006, 53).

6 This included a number of non-scientific publications describing and celebrating Circassian history and culture. Some of which expressed harsh opposition to official Russian history writing and/or managed to offend neighbouring peoples - whether ethnic Russians or other Caucasian groups.
} 
on the Internet - mostly free of charge. ${ }^{7}$ Within a few years of 1991, electronic media began to gain importance in several of the North Caucasian republics, with a limited number of weekly hours of programming in the Circassian language on issues of Circassian history and traditions, which became very popular among audiences, as I observed during my field work in the 1990s. The 1990s were, for the Circassians in Russia, marked by an overlap of print and electronic capitalism, partly due to the delay of almost 150 years due to censorship and other restrictions on the free publication on issues relating to the Circassian minorities.

As an extension of the above-mentioned terms of Anderson and Appadurai, I have chosen to use the term 'digital capitalism' to designate the contemporary period dominated by the features of the so-called Web 2.0..$^{8}$ This is an updated version of the two preceding periods of print and electronic capitalism, representing a third phase of media technological development. Jürgen Habermas has stressed how only with the arrival of modernism did the printing press "unfold its cultural and political significance". "It brings with it an enlargement of the communicative action which, by means of electronic mass-communication, as developed during the $20^{\text {th }}$ century, has been intensified once more" (Habermas 1996, 366 - my translation). ${ }^{9}$ Extending the theory of Benedict Anderson, the current period of digital capitalism could be characterised as yet another period of intensification. This (gradual) shift from electronic towards digital capitalism more than illustrates the role of speed and acceleration in this process. We are witnessing a profound shift in form and practice of mediation since the arrival of Web 2.0, which potentially has significant consequences for

7 Books published by Circassians and other Caucasians in the diaspora countries are also now translated and published in the North Caucasus.

${ }^{8}$ The term 'digital capitalism' is also used by Dan Schiller in his book of the same name from 2000, where he mainly investigates the new economic landscape defined by the interface between neo-liberalism and the Internet.

${ }^{9}$ The contemporary phase of digital capitalism is also characterised by a more transnational, global or cosmopolitan outlook compared to the phase of electronic capitalism of the 1990s, which was more state-centric. 
memorialisation and mobilisation - as the case of the Circassian revival illustrates.

The shift to digital capitalism experienced since the mid-2000s has contributed significantly to the reproduction and acceleration of the contemporary Circassian cultural revival. Characterised not just by the newfound dominance of the Internet as a media but also the integrated multi-media character of the Internet, with features such as hyperlinking, remediation, cross-mediality etc. Two main characteristics of the Internet can primarily be emphasised: firstly, the element of convergence of media forms and technologies that is illustrated by, for instance, the integrated use of 'older' media forms such as photos and films on social media sites and other parts of the Internet. This is sometimes referred to as 'new media' (Manovich 2001). Secondly, the Internet functions as an enormous digital storehouse, as a media form that is technologically based upon a database model (Manovich 2001, 55). These two twin characteristics of the contemporary Internet - or digital capitalism - to a large extent encapsulate the digital aspects of the ongoing Circassian revival.

\section{Re-Imagining Circassia}

The fall of the Soviet Union in 1991 led to a re-imaging of the Circassian homeland as a key element of ethnic identity, both in the North Caucasus and among the Circassian diaspora - through a number of different processes and forms of expression, including a revival and reproduction of the 'imaginary geography' of the nineteenth century, as described earlier in this chapter. Seteney Shami has stated the following regarding the diaspora Circassians and the new role of the homeland: "The encounter with the homeland has brought this space back into time and has made it into a territory" (Shami 1998, 642). Since then the Internet has played a significant role in the process of what could be labelled a virtual 're-territorialisation'. This could be labelled 'iCircassia', which in many ways is also a way of contesting the situation on the ground in the contemporary Kuban region (formally Krasnodar Krai) and other parts of historical Circassia.

Images of the contemporary homeland - the nature, the people, the traditions, the built environment etc. - are presented on many 
websites, ${ }^{10}$ both in the form of products presented by professional media outlets and as amateur photos and films by tourists and other travellers that have visited the region, including some from the Circassian diaspora. ${ }^{11}$ After a slight delay, the Circassians in the homeland now also add to this joint pool of Circassian images, which is expanding on a daily basis. ${ }^{12}$ Together with the many examples of remediated nineteenth century representations, these many digital Circassian images constitute a visual virtual version of Circassia. ${ }^{13}$ The historical homeland becomes more visible, not just for the members of the dispersed diaspora but also for the rest of the world. A contested European periphery becomes slightly more visible to the rest of Europe.

One of the questions, raised by the emergence of 'InternetCircassia' and the Circassian digital diaspora, is whether this phenomenon will reduce the desire to repatriate among the diaspora. Repatriation is one of the most difficult issues facing the Circassian diaspora organisations, many of which have formally prioritised repatriation since the $1990 \mathrm{~s} .{ }^{14}$ As noted by Khachig Tölölyan, the option of performing a virtual 'return' - a repeated turning towards the historical homeland through the Internet could replace or reduce the will to actually repatriate (Gibb 2006,

\footnotetext{
${ }^{10}$ Imagology, sometimes referred to as 'image studies', is the analysis of the use of national and ethnic stereotypes in literature (and other cultural productions), which is a related way of discussing the production of national or counter-national images - and imagined geographies (Beller and Leerssen 2007).

11 Tourists are increasingly contributing to the creation of a worldwide digital repository of visual images of places all over the world. Within this worldwide digital archive, Circassian trajectories can increasingly be found. 12 Including a central role for many of the territorial symbols, such as the flag, the nineteenth-century costumes, historical maps etc.

13 These virtual visualisations share similarities with the so-called 'reversing of the imperial gaze' described in a number of post-colonial studies, including Edward Said and Derek Gregory. Now this process of reversing has taken on a new form that could be labelled a 'digital gaze'.

14 Many of the newer organisations criticise the older organisations for talking about repatriation, while rarely taking concrete steps to push forward an agenda on the issue.
} 
175). Camilla Gibb has investigated the Harari diaspora, which originates from Ethiopia, including how they "construct, circulate and consume images of the homeland over the Internet", and this could be relevant to consider in relation to the Circassian experience. "Because, as Appadurai (1995) notes, "The homeland is partly invented, existing only in the imagination of the deterritorialized groups", the Internet is one place where that imagination can speak in visual, textual and interactive terms" (Gibb 2006, 175). And Gibb further notes that "the loosening of the ties between people and place has fundamentally altered the basis of cultural reproduction" (Gibb 2006, 176). The arrival of the social media of Web 2.0, and the Internet in general, has contributed to enlarging and transnationalising the Circassian civil society sector significantly. Among the Circassian diaspora, this has led to the increased involvement of youths and others with an interest in using the Internet, to a much larger degree than before, in producing, circulating and discussing Circassian content. Establishing links through Internet media as an informal but still acceptable way of bypassing the formal structures of the older organisations has proven both appealing and successful especially for the young generation (Besleney 2014, 160). The Internet has turned out to be a highly appropriate tool for the twin task of mobilising Circassians for action (online as well as offline) and promoting what Gibb refers to as 'cultural reproduction'. As mentioned, the threatening loss of Circassian language and culture in general is one of the key mobilising factors among the new generation of on- and offline activists. As also noted by Gibb in relation to the Harari, the role of transferring knowledge of history, culture and traditions, which used to be the role of the elders, has today partly been taken over by the Internet. ${ }^{15}$ Here, digital activists not only advocate contemporary Circassian issues such as genocide recognition but also promote Circassian identity by taking

\footnotetext{
${ }^{15}$ This has, to some extent, marginalised the elders, though many of these have also relocated to urban settings, where they are often active in various associations. As mentioned elsewhere, the threatening loss of language is an issue that is lamented by many Circassians. This could turn out to be the 'collateral damage' of a successful Circassian revival.
} 
part in the production and reproduction of a digitalised version of Circassian cultural heritage. All in all, it is obvious that this development has contributed to invigorating the Circassian revival. $^{16}$

There are a number of different ways of practising 'longdistance relationships' with a distant, mythologised and mostly unseen homeland among the Circassian diaspora, whether on the part of associations, organisations or individuals. This diversity is also reflected in the five main strands of the contemporary Circassian movement identified by Sufian Zhemukhov as ranging from 'nationalists' at one end, through 'sovereigntists', 'centrists' and 'culturalists', to 'accommodationists' at the other end of the spectrum (Zhemukhov 2012). The nationalist stand is the one most widely discussed, as illustrated by, for instance, Benedict Anderson, who has used the terms 'mobile nationalism' or 'long-distance nationalism' to discuss the phenomenon of 'Internet nationalism' (Conversi 2012, 1361). Here, love of the homeland can grow strong - at a distance - while the homeland is often fetishised, and assimilation into the country of residence can become a form of treason. This is basically an intensification of the already wellknown phenomenon of 'diaspora nationalism' described by, among others, Anderson (1983/1991), and Schiller and Fouron (2001). Since nationalism only marks one end of the contemporary Circassian movement, albeit often the most visible and catchy one for news media in different contexts (used and misused for different purposes by different actors), it could be relevant to include assessments of the other four stands as well in order to achieve a fuller picture of the 'creation of iCircassia', although this is beyond the scope of this chapter.

Thomas Hyland Eriksen has also elaborated on the relationship between nationalism and the Internet. He identifies "four varieties of Internet nationalism: State-supported (Chile), surrogate

\footnotetext{
${ }^{16}$ Most of the elders that I have met at conferences, in cultural associations and elsewhere have welcomed this trend and often expressed pride in the renewed level of activity. I have not talked to elders in Circassian villages in the Caucasus or, for instance, in Turkey to see whether they have reservations regarding this development.
} 
(Afrikaner), pre-independence (Kurdish) and multiculturalist (Moroccan-Dutch)", which he then supplements with two more, which are not included in his analysis: 'oppositional' and diasporic identities with weak links to homeland. (Eriksen 2007, 14). ${ }^{17}$ The case of the Circassian Internet revival does not fit easily into any one of the categories but the most visible part of the Circassian activism, focusing on genocide recognition and protesting against the Sochi Olympics, particularly shares similarities with 'preindependence' and 'opposition'. However, as mentioned above, nationalism is just one aspect of the Circassian revival. Eriksen notes that the Internet is creating "an invisible, but perceptible umbrella covering scattered diasporas in numerous countries" and stresses that, with the arrival of the Internet, a certain form of identity is more likely to persist than before, when "encapsulation or assimilation were the most likely outcome" (Eriksen 2007, 15). This relates to identities such as, for instance, German Circassianness or American Circassianness. In other words, the Internet contributes to the creation of new forms of hybrid identity, and this is relevant to include in an assessment of the Circassian context.

'Internet-Circassia' is multi-lingual, though the netizens of iCircassia generally belong to certain linguistically-defined spaces within the virtual part of the Circassian world. However, these spaces are increasingly overlapping. This is partly due to the growing knowledge and use of English and to the rising use - and usability - of Internet-generated functions such as Google Translate. Just a few years ago, iCircassia could be defined as consisting of almost separate linguistically-defined zones, especially Russian, Turkish and Arabic, with English functioning as an addition together with a few other languages. The role of the Circassian language on the Internet has also expanded as a zone that (potentially) cut across the other linguistic zones (as does English also) but a general lack of knowledge of the Cyrillic

17 Anna Everett $(2009,34)$ has noted that 'cyber-nationalism' can potentially challenge 'old-nationalism'. Cyber-nationalism can thus question fragile balances between groups and potentially lead to conflicts. Such concerns have occasionally been voiced in relation to the Circassian revival. 
alphabet is impeding this development. Still, many new possibilities of learning and using the Circassian language through the Internet have evolved and, similarly, the possibilities of linking up with likeminded people have increased. These linguistically-defined zones not only constitute significant parts of iCircassia today but have grown with the arrival of new websites and, in particular, with the growth in social web media. This is a reflection of the diversity of the geographically scattered Circassian population which, however, with the growing role of the Internet, is increasingly converging.

As part of the accelerating process of globalisation, minority languages such as Circassian appear to become further marginalised, as ongoing processes over a number of years are further enhanced due to the geographically dispersed nature of the Circassian communities. ${ }^{18}$ The Internet is now being used to counter this situation by promoting different forms of language training, for instance through the use of YouTube, where a mixture of pedagogical methods and aural examples can be applied. Whether this will contribute to saving the Circassian language from extinction is questionable, and opinions among Circassian activists differ as to whether language survival should be a key element of the Circassian revival. Still, many Circassians refer to loss of language as a sign of assimilation and loss of culture, and thus as part of their motivation to become active participants in the Circassian revival. ${ }^{19}$ It should be noted that, for instance, the

\footnotetext{
${ }^{18}$ A large part of the Circassians lived on the Anatolian mainland for more than six generations but during recent decades, they have experienced a secondary displacement, albeit this time mainly voluntarily. A new generation of Circassians now dwells in Istanbul, Ankara or in large urban cities in Germany, Holland, Belgium etc. and, to many of those Circassians, regions in Central Anatolia have become a second lost homeland.

19 The fear of assimilation can be seen, for instance, in Turkey, where a large number of young Circassians have lost the Circassian language that their forefathers had managed to keep alive for six or seven generations in exile. This is an illustration of one of the contradictions of late modern globalisation whereby Turkish as a daily language in the main urban centres, in the media and in education has achieved a more dominant
} 
relatively few Circassian youth activists among the diaspora that speak the Circassian language, evidently command respect from their peers.

Initially, the rather low level of Internet action was not merely due to government control and a lack of access in the Russian North Caucasus and in Turkey but was also due to a lack of equipment and computer and language skills. A digital and linguistic divide still had to be overcome but, both in Turkey and in Russia, this situation is changing quickly, spearheaded by the young generation especially. ${ }^{20}$ The increased role of the Internet also increases some of the generally well-known negative side effects, such as hate-speech, xenophobic or ultra-nationalistic remarks both towards and by Circassians. A former Circassian diaspora activist referred to 'stupid nationalism', as occurs on the Internet, as a demotivating factor for him. This element has increased with the growing role of the Russian Internet sphere in the Circassian revival - xenophobic tendencies are widespread in Russia, and the Internet has proven to be a significant field of xenophobic clashes. The widespread xenophobic attitude towards Caucasians in Russia, which also unfolds on the Internet, similarly affects the Circassian Internet context. ${ }^{21}$

The following three examples illustrate the diversity of InternetCircassia, while also demonstrating the (increasing) level of connectedness that is one of the key characteristics of the Internet. Firstly, the use of viral videos: short films or video clips that can instantly be shared through all web-based media platforms and

position than before, while English is increasingly becoming the second language.

${ }^{20}$ As noted by John Phillip Schaefer in his discussion of 'iGhana': "Literacy is again required, and a computer literacy is now prerequisite. There is thus a digital divide that challenges the role of electronic capitalism in the formation of an imagined community of the nation-state" (Schaefer 2006, 211).

21 An unknown factor is Internet-trolls, who sometimes are hired by intelligence agencies. 
which have often been inexpensively produced. ${ }^{22}$ These are now regularly produced and circulated by a number of organisations in relation to the annual May 21 events, both for online promotion of events and for use at commemorative events, conferences etc. These videos are often short (for instance 2, 5 or 10 minutes long) and may be in local languages but often with a visual representation that can be understood without knowing the actual words uttered in the video. The content often includes historical images from the nineteenth century, digitalised and/or remediated for use in these videos, which can also be used to inform wider target groups about Circassian history and identity after these events. The form of the video often varies from year to year - one example of a different format is a viral video made by the youth activists at the Circassian Cultural Institute in New Jersey in May 2011, in which they filmed each other while telephoning the Russian embassy in Washington, all asking the same question: "Where is Circassia?" The form varies greatly, however, as organisations are becoming increasingly aware that they should not use the same formula from year to year. Viral videos are typically uploaded onto YouTube and further circulated through sites such as Facebook and Twitter, not just by organisations but also by individuals. These sites have become important supplements to the websites of the Circassian and Caucasian organisations and other initiatives and, in some cases, the main activities have moved to the social sites. Viral videos have become a new tool for civil society actions and campaigns, one that is cheap and easy to use, as illustrated by the Circassian activists, many of whom form part of an organisation. Their role is crucial as facilitators (initiating and maintaining) of the processes of sharing and connecting - partly related to what Malcolm Gladwell - in a slightly different context - has called 'influencers' (Jenkins 2009). ${ }^{23}$

22 On the use of viral videos as part of (viral) campaigning (Obama for President), see Kevin Wallsten (2010).

${ }^{23}$ Gladwell has analysed the functioning of social networks or media including how and when certain cultural phenomena go viral. He use the terms 'connectors' and 'mavens' to assign key persons or actors, where the latter represents persons with knowledge and information, and the former 
Obviously, a number of different forms of cyber-activism can be anticipated to emerge in the (near) future. ${ }^{24}$

In 2009, new transnational cooperation began among a number of leading Circassian and Caucasian organisations of the post-2005 generation (CR2). This was centred on cooperation, coordinated action and exchange of promotional material (slogans, poster design), videos etc., as illustrated by the May21.org site. Since 2010, May21.org opened a YouTube channel, where some of the viral videos from the campaign can still be seen (three videos as of 20-06-2012). Many videos documenting the May 21 actions in various places around the world can also be seen (21 videos as of 22-06-2015), along with a large number of digital photos (that can also be found on a number of other sites). ${ }^{25}$ These organisations, along with a few more, are also part of the parallel initiative, NoSochi2014.org (Kaya 2014, 60). NoSochi was a topic that increasingly achieved a central position in May 21 events and initiatives in the years leading up to the 2014 Sochi Winter Olympics (Besleney 2014, 163). A NoSochi2014 YouTube channel was opened in 2010 and, by February 2014, it was showing ten videos that had been played more than 30,000 times. On YouTube in general, there are more than a hundred films on Circassians and 'May 21' (10-07-2013), most of which cover events such as demonstrations, commemorational ceremonies, conferences (of different lengths and detail), while a smaller number of films use 'May 21 ' in the title or subtitle of films on Circassian history and identity. These can be seen on the YouTube channel of May21.org, where activists and others are encouraged to do the same in their national contexts. This film was presented in negative, which adds visual drama to the story. In 2010 , they presented a film that also

those with large networks that enable them to circulate information and knowledge (Gladwell 2002).

${ }^{24}$ As stated by Wallsten $(2010,163)$ in relation to the "Yes We Can" campaign of the American elections in 2008, these actors "seem to occupy a unique and influential position in determining whether an online political video goes viral".

${ }^{25}$ By July 2013, the 'May211864' YouTube channel had been viewed more than 28,000 times. 
featured activists (15 persons) being asked "What is your message to other Circassians?" These are both examples of the use of a contemporary format that avoids nineteenth-century images, and which could perhaps considered more appealing to contemporary cosmopolitan youth activists. A related example is the film from May 2013 made by representatives of the Caucasian Forum from Turkey and also circulated via the May21.org YouTube channel as well as their website, Facebook site etc. (in Turkish with English subtitles).

The number '21' has become an icon - also a visual icon - of the Circassian revival (CR2), NART-TV produced a 61-minute-long documentary entitled ' 21 ' (with the subtitle "The Circassian tale of suffering and pain") based on a dialogue with a Circassian researcher, interviewed in Circassian and Arabic (with subtitles in English). ${ }^{26}$

A significant number of short (and longer) videos on Circassian history and identity have been produced and circulated on YouTube by organisations as well as by individuals. These generally rather simple vernacular film productions mostly reproduce visual representations of the Circassian exodus from the Caucasus in the nineteenth century - a large part of which are the same images that have achieved iconographic status in the Circassian revival. Many of these images had already been reproduced in books and other publications but with the arrival of the Internet - and not least the contemporary second-generation - these images have been digitalised, remediated and circulated to a much larger degree. YouTube video clips are also used to promote other cultural products such as the films 'Cherkess' (2010) and 'Homeland' (2013). The making of these films, could in both cases, be followed during the years of production, which generated an increased interest among the Circassian or Caucasian audience. This illustrates the potential interconnectedness of Web 2.0 and its

\footnotetext{
${ }^{26}$ Nart TV is a Circassian satellite TV station that began as a voluntary project in Jordan in 2007 but now also has branches in two Circassian republics in Russia. Its aim is to promote the use and preservation of the Circassian language and many of its broadcasts are in the Circassian language.
} 
usability as a tool in campaigning, which can have wider or different aims than just promoting a product such as a film.

One of the strengths of the video as a media type, according to Bonnie Nardi, is its potential to generate affinity or "feelings of connection between peoples" and this can establish a form of social bonding (Lange 2009, 73). ${ }^{27}$ This is also so when played during commemorative events.

According to Snickars, YouTube has become the world's largest archive and we are still in the early phases of investigating how this will affect cultural memory in general (Snickars 2009, 293). The significant Circassian use of YouTube indicates, however, that this has become a significant platform for media productions and one that is regarded as important in order to reach the relevant audiences. Snickars refers to the archive as "a kind of guiding metaphor for the contemporary digital landscape", which includes not just YouTube but also Flickr, Instagram and others (Snickars 2009, 303). As stated by Lawrence Lessig, YouTube can be understood as a kind of "community space" - "a virtual place where people interact, share information or interests" (Snickars 2009, 309). Still, for instance, the NoSochi2014 YouTube videos and channels generate a number of hostile and xenophobic comments, some of which have been marked as 'spam'.

Many of the above-mentioned YouTube videos represent what could be labelled 'YouTubian memorialisation', which is a relatively new genre that includes individual as well as collective remembrance produced on a vernacular basis on a low budget. In the case of the Circassian vernacular YouTubian videos, they often consist mainly of nineteenth-century images such as still photos, paintings, maps, illustrations from books, museum items etc. that are filmed in different ways (e.g. zooming in on details) and then cut into a short film. When these videos are shown at commemorative events such as May $21^{\text {st }}$ or at conferences - often accompanied by sad Circassian folk songs, often laments related to the exodus - it often leads to emotional responses from the

27 A classical example of YouTube-generated vernacular memorialisation are the videos commemorating deceased individuals, as also noted by Wahlberg $(2009,218)$. 
audience. Whether this form of affective response also is taking place when audiences are alone in front of the computer screen is difficult to assess. Anyway, YouTubian memorialisation has become a significant cultural genre within the contemporary Circassian revival (CR2) and the number of 'memory-entrepreneurs', to use a term from James $E$. Young, has increased many times.

A second example comes from the Circassian activists from New Jersey who use the term 'Facebook revolution' in reference to the new modus operandi they have adopted since the arrival of Facebook. ${ }^{28}$ Here, new linking opportunities ('likes' or 'friends') sometimes transnational, sometimes national or even local - are used by activists to develop further relationships and exchange information and knowledge. ${ }^{29}$ This can function as a negotiation on how to define Circassian culture and identity that can be performed both openly and publicly, making it possible for others to participate. It can also be performed just between two individuals. This is an example of a method that can be used to strengthen an understanding of the Circassian exile as genocide, and perhaps engage new cyber-activists who can continue these promotional efforts through the continued process of sharing within their networks. This process has been labelled as "thickening of networks (linking, developing dense networks, thickening networking)" and can now become a strategy of Internet-based activism. ${ }^{30}$

Thirdly, the promotion of genocide recognition, which is a topic

\footnotetext{
${ }^{28}$ The young activists meet in the offices of the Circassian Cultural Institute $(\mathrm{CCl})$ two or three times a week and perform these actions jointly - so the social offline face-to-face aspect still seems important and can be motivating for this type of activism. They have presented themselves on YouTube via the video "Behind the scenes at the Circassian Cultural Institute" (15-09-2011).

${ }^{29} \mathrm{CCl}$ also has its own YouTube channel with 13 videos as of July 2013, most of which consist of hour-long filmed presentations by lecturers.

30 Valtysson has analysed whether Facebook "represents a colonizing mediatisation of the lifeworld" or whether it represents an 'emancipation' or 'empowerment' as 'digital cultures' or 'networked publics' can use Facebook to reach audiences and set agendas (Valtysson 2012).
} 
addressed in both of the two former examples of viral videos and the 'Facebook revolution'. Archives have been researched, results digitalised and made available on websites such as circassiangenocide.info where, for instance, documents from Russian and Georgian archives are presented. ${ }^{31}$ This is a process still in its early phases and much more archive material can be expected to be made available in the very near future, some of which is already available in books. Digitalised testimonies from various nineteenthcentury sources are also published on the Circassian-genocide.info site including newspaper reports, Russian army reports, letters from Circassians etc.; these or similar testimonies are regularly circulated on the Internet in relation to May 21 events.

Perhaps the most important aspect of these examples is how they show an increasing tendency towards linking (hyperlinking). Connectivity and spreadability, to use a term from Henry Jenkins (2009), play a significant part in all these examples. ${ }^{32}$

\section{Discussion: Digital Mediation}

The digital shift marked by the second generation Internet, signified especially by the interactive elements of social media such as Facebook, Twitter and YouTube, has resulted in a radically new use of the media - both in terms of form, content and utilization. According to Kraidy and Mourad, the emerging global media environment can best be understood as a transnational "hypermedia space", which includes terms such as media convergence, remediation, cross-mediality, intermediality, hyperlinking, interactivity etc., whereby older forms of media can

31 For instance, the book 'The Circassian Genocide' by the American historian Walter Richmond is already - partly at least - one of the results of the recently researched and digitalised archival documents. As stressed by Cohen and Rosenzweig, the 'new digital history' will provide space for both contemporary and historical voices - for instance minority voices - that otherwise would not have surfaced (Cohen and Rosenzweig 2006, 248). They outline seven qualities of digital media and network that could potentially improve the work of historians (Cohen and Rosenzweig 2006, 3). 32 Jenkins has applied the notion of 'gift economy' to explain spreadability especially in relation to Twitter (retweeting etc.). 
be combined with new ones in a number of different combinations (Kraidy and Mourad 2010, 1; Livingston 2009, 3; crossmediacom.dk). This includes, for instance, "the move from photography to its digital recycling" (Huyssen 2000, 9). Kraidy and Mourad analysed the role of social media and mobile telephones in civil society actions and demonstrations in Lebanon in 2005 and in Iran in 2009 which, in many ways, formed a prelude to the Arab Spring from early 2011. ${ }^{33}$ They concluded that: "Hypermedia space's importance resides in the ways in which it combines mobility, interactivity and visibility. We can now glimpse the contours of a theory of hypermedia in which mobile activists interactively activate inter-media configurations that connect media old and new, gaining visibility for their cause through a hypermedia space that is less controllable than social space and therefore potentially subversive of the prevalent mode of governance." (Kraidy and Mourad 2010, 11). Kraidy and Mourad here point at some of the key reasons why further elaborations of 'hypermedia space' are relevant to discuss in relation to digital capitalism. For instance, key issues of hypermedia space such as remediation and circulation in combination illustrate how digital media is particular relevant and useful for a process of mobilisation, where mediated memorialisation plays a key role (Himpele 2008, 15; van Dijck 2007, 49).

Some argue that the new hypermedia space has ultimately not managed to affect the end results of actions but, on the other hand, some of the successful actions and events during the Arab Spring demonstrate that some results have been achieved (Kraidy and Mourad 2010, 15). Whatever the outcome - an empowerment and mobilisation of civil society actors has taken place. This is a type of empowerment that can be applied in different ways in years to come. The civil society actions of a peripherally located Caucasian minority group cannot, however, expect support from potential civil society partners in the central parts of Russia. Various human rights groups might support the rights of the

${ }^{33}$ Post-Soviet examples of similar processes of civil society mobilisation include, for instance, Moldova, April 2009 and Russia, December 2011 (www.russiablog.org 17-04-2009). 
Circassians but are generally fully employed in documenting various forms of human rights violations while simultaneously under pressure from the authorities. The Circassian scenario is therefore quite different from that of the countries of the Arab Spring, and the new potential for linking Circassians in the homeland and the diaspora may turn out to be a difficult balancing act, in which local Circassians could be accused by Russia of being disloyal citizens.

Diaspora groups often constitute a specific interface within the contemporary discussions on mediation, and this is reflected in the term 'digital diaspora', which often entails new forms of community building. As a field of study, this has become a meeting point between migration and media studies, and has inspired parts of this paper. (See below on the V.E.R.A.city loop model).

Cyberspace can function as a space for identity negotiation which can be both qualitatively and quantitatively different from earlier forms of mediation. In relation to such negotiations, identity can be put into practise differently from offline communities of, for instance, Circassian associations, where people tend to come for cultural activities such as dance lessons, to play a game of chess, to speak Circassian etc. (Brinkerhoff 2009, 57). This can lead to the establishment of cyber-communities: "The interactive components of the Internet enable the creation of cyber-communities that connect dispersed populations and provide solidarity among members" (Brinkerhoff 2009, 14). This corresponds to the experiences of the sprawling Circassian Internet community, though it should be noted that this community is highly heterogeneous and consists of a number of sub-communities. ${ }^{34}$ Brinkerhoff further concludes on the potential functionalities that: "The Internet may be an essential repository of information about the homeland, providing opportunities to continuously educate subsequent diaspora generations, as well as more general publics"

34 For instance, the discussions in relation to a Facebook group or a YouTube video can be quite different from the more internal discussions on the forums of the websites of Circassian organisations. 
(Brinkerhoff 2009, 57). ${ }^{35}$ This is an illustration of why the Internet can potentially function as a powerful tool in relation to the processes of both memorialisation and mobilisation, which I investigate in relation to the ongoing Circassian revival process. It also illustrates one of the key differences between the phases of 'electronic capitalism' and 'digital capitalism'.

According to Jeff D. Hempele, "...Martin-Barbero argues that the 'mediation' of transnational media in circulation has meant an upsurge of new cultural identities and practises, the anthropology of media has elaborated on mediation as a fundamental constituent of social and cultural reproduction" (Himpele 2008, 11). The kind of 'upsurge in new cultural identities and practices' described by Jesus Martin-Barbero corresponds with the Circassian context - especially as mediated and unfolding on the Internet. Himpele has further concluded that the important role of media in relation to indigenous revival (Himpele, 199) ${ }^{36}$ - is what he refers to as 'techniques of empowerment' (Himpele, 212). According to Himpele, the indigenous media producers in this process asserted control over the circulation of Indianness. ${ }^{37}$ This, in many ways, corresponds with Circassian experiences, although the degree of empowerment obviously differs in different Circassian contexts. Russia constitutes a complex federal context in which issues of domination, but also of competition and resistance, unfold. Still, the process of reproduction and circulation of Circassian

${ }^{35}$ More on the role of the 'total archive', the 'repository of information' and the 'database character' of the Internet in relation to the discussion of memorialisation later.

${ }^{36}$ Also on how in Bolivia - through media, tourism etc. - the term 'indigenous' came to be connoted with the national past (Himpele 2008, 199).

${ }^{37}$ Much of the Circassian revival is about recognition of Circassian history and identity as part of a larger Caucasianness. This can also be seen as a way of challenging the Caucasianness that Russia is building in relation to the Sochi Olympics where historical authenticity is promoted through the connections to historical Greece (through archaeological excavations, legend of Prometheus and Fisht Mountains, which the Olympic stadium, where opening and closing ceremonies took place, is named after), and not through the local indigenous populations as in Vancouver and Sydney. 
indigenousness takes place on a number of different levels especially on the Internet. In a Russian context, it is relevant to discuss the potential differences between state-supported mediation and sub-state level processes taking place in the North Caucasians republics, where actors such as the Circassian organisations and their representatives are facing different kinds of possibilities and barriers.

One of the paradoxes of Internet use by diaspora and other forms of migrant groups is that, on the one hand, the world has witnessed an interlinked de-territorialisation through the Internet and electronic mass media that can float freely across state borders while, on the other, this de-territorialised digital media can be used to perform acts of virtual re-territorialisation.

Fred Turner states the following conclusion on the development of the Internet: "I conclude by arguing that Brand's entrepreneurial tactics, and the now widespread association of computers and computer-mediated communication with the egalitarian social ideals of the counterculture, have become important features of an increasingly networked mode of living, working, and deploying social and cultural power" (Turner 2006, 9). Turner also quotes the Mondo 2000 magazine with the following statement: "Digital technologies had inherited the transformational mantle of the counterculture" (Turner 2006, 164). ${ }^{38}$

According to an investigation by the BBC, by 2010 four out of five people worldwide regarded it as a fundamental human right to be able to access the Internet. ${ }^{39}$ Persons from Mexico, Brazil and Turkey particularly supported this statement. ${ }^{40}$ According to the General Secretary of the International Telecommunications Union (ITU), Hamadoun Toure: "The right to communicate cannot be ignored." And he further underlines the fact that: "The Internet is potentially the most powerful source to enlightenment ever created". ${ }^{41}$ Toure further states that governments around the world should view the Internet as a fundamental part of

\footnotetext{
${ }^{38}$ Turner also refers to cyberspace as an 'electronic frontier'.

${ }^{39}$ Politiken.dk (09-03-2010 - my translation).

${ }^{40} 27,000$ adults in 26 countries were questioned.

${ }^{41}$ Politiken.dk (09-03-2010 - my translation).
} 
infrastructure similar to roads and water. ${ }^{42}$

The tendencies outlined above underline the relevance of discussing the four main elements of Maximillian Forte's analytical model on Internet-mediated indigenous revival, the so-called V.E.R.A.city loop, which I find relevant to include in the discussion of the Circassian case. 'V.E.R.A.' stands for visibility, embodiment, recognition and authenticity - these four themes are linked in a continuous loop-function as new material is constantly produced and presented on the Internet. A loop of processes whereby "online visibility [is] helping to virtually embody groups who might not otherwise be noticed or distinguished and who - given this virtualized visibility and embodiment - subsequently gain recognition from prospective allies and brokers. Depending upon the reputation of one's ally, the fact of being recognised itself adds authenticity to a particular, previously under-recognised group's claims to 'real indignity' (Forte 2006, 146).

The role of visibility must be said to be obvious, as also illustrated by the many references in this article. Visualisation does not just include images and films but also all sorts of written documents from historical archives and other written texts. This visualisation also represents a virtual embodiment of Circassianness (Circassian history and identity): "The Internet also helps to embody groups facing difficulties in gaining offline acceptance as "indigenous'" (Forte 2006, 146). Thirdly, recognition, the importance of which Linda T. Smith has also underlined by claiming that 'recovery' (of territories; indigenous rights; and histories) is part of the recognition that contemporary indigenous people seek (Smith 1999, 116). It is this kind of recognition that the Circassian activists are advocating for and that the increasing amount of historical and cultural documentation on the Internet helps to generate. Upon visiting a number of Circassian places around the world, interviewing and reading (including on the Internet), it is my conclusion that 'recognition' is the one word or term that most clearly encompasses the aims of the diverse

42 The survey also included criticism of various kinds, including the possibilities for presenting violent content, for becoming a new field of criminal activity, for government censorship etc. 
Circassian revival(s). Fourthly, this recognition contributes to providing "further authority and authenticity to any given group in its respective offline context(s)" (Forte 2006, 146). ${ }^{43}$ Forte argues that it is through this process that the V.E.R.A.city of "indigeneity is sought and attained by electronic means of promotion" (Forte 2006, 146).

As indicated on several occasions, the Circassian revival is not just virtual or only unfolding in cyberspace. Offline civil society initiatives have, to a very large extent, been initiating and driving the Circassian revival process forward. However, the arrival of the Internet, which has been a gradual and slow process in many areas of Circassian residence, has offered a new dimension to the revival, as it has extended and accelerated this process. ${ }^{44}$

The high number of Circassian sites on the Internet marks a significant change in a process of mediated Circassian revival that, in a Russian context, began in the 1990s in the North Caucasian republics through other media forms. Many Internet sites now represent a counter-narrative or resistance to the official Russian version of history, and share similarities with post-colonial actions and protests in other post-imperial settings. As noted in the Black Book of Colonialism, the Russian Federation of today constitutes a surprising imperial successor state, one that does not accept or

\footnotetext{
43 Authenticity as fundamental to creating and sustaining a brand: for instance, regional or national belonging. Or, on a different level: cheese production in Circassian parts of the North Caucasus as demonstrated to tourists and then sold. Authenticity is in the combination between marketing and regional branding thought to be the decisive element. Regional branding can include an element of counter-branding vis-à-vis the dominant nation branding.

${ }^{44}$ Until the mid-2000s Circassian civil society was largely dominated by cultural associations and primarily focussed on cultural or folkloristic issues. The wars in Abkhazia and Chechnya in the early 1990s marked an initial mobilisation among Circassians in Turkey. Another significant precursor to the present revival was the establishment of Caucasian foundations which, due to an option in Turkish legislation for establishing philanthropic foundations, had been involved since the 1950s in preserving and collecting Circassian archival material, thereby establishing important and unique book collections.
} 
recognise its former status (Ferro 2005). The Internet has become a space in which such inconsistencies can be pointed at, discussed and possibly used in a campaign for alternative versions based on documentation, as seen in the case of the Circassian revival. This type of mediated resistance has regularly been analysed within literature, media and cultural studies, although often with a focus on 'high culture' as also illustrated by, for instance, Edward Said. The ongoing mediated and remediated Circassian revival illustrates the use of a variety of media tools to conduct what could, perhaps, be labelled a vernacular (post-) colonial encounter. In conducting these kinds of calls for a reassessment of the history of the Russian Empire, the Circassians are part of a trend found among several of the peoples of the Caucasus as well as several of the countries of the former Soviet Union.

\section{Concluding Remarks}

In conclusion, then, there is a need to update the term 'electronic capitalism' to 'digital capitalism' - or 'digital mediation' - in order to encompass the increasingly widespread, fast and accessible Internet, with its increased interactive functions and social media such as Facebook, YouTube and Twitter. In addition, the increased role of mobile communication units and the database nature of the Internet signifies a fundamental difference vis-à-vis other forms of media. The products of both electronic and digital capitalism are often highly visual. Websites are visual and visualisation plays a key role. As noted by Schaefer, there is an "extensive representational power of the online universe" (Schaefer 2006, 213). This element of visualisation that is so prominent on Circassian websites also illustrates the importance attributed to authenticity and recognition through the presentation of different forms of historical documentation, especially from the nineteenth century. It should be noted that this includes not only the sources sympathetic to the Circassians in the nineteenth century but also other voices, including those who believed in the brutal implementation of an enforced civilising mission ('they may have died in the process but we have built new roads...'). This includes, for instance, the memoirs of Russian army officers, some of whom 
express their pride in winning the war through extreme methods. These today function to enhance the understanding of a highly unjust colonisation that could be labelled as an attempt at genocide (Richmond 2013).

The most important features of digital capitalism or mediation compared to earlier forms of publishing can be summed up as: the arrival of the social media of Web 2.0, the database nature, the hypermedia character, the hyperlinking options, the interactive features of social media, the low-cost production options, the arrival of new and cheaper mobile user and producer units. Jointly, all of this signifies the increased diversity of media, mediation and remediation that constitutes the strongly mediated post-2005 Circassian revival (CR2).

It could be argued that iCircassia has become a significant part of the Circassian World, often referred to among Circassians as consisting of fifty places (or spaces) of residence around the world. However, iCircassia cannot merely be labelled the fifty-first Circassian place. It could be argued that the Circassian World no longer consists of simply the sum of the homeland and the diaspora Circassians but today also includes iCircassia - in spite of the fact that all the netizens of iCircassia belong to the two former categories as well. What makes iCircassia a new and independent addition to the Circassian World is that this is not just a medium of communication but simultaneously a network of links between different Circassian offline places that might otherwise not have been connected. It is also a large repository of knowledge which, through digitalisation, has become available to Circassians around the world as well as to everybody else. All of this digitalised knowledge is not only available but also shared, used, discussed and reproduced through the aforementioned features of linking and communicating. All in all, iCircassia is more than just a global network - it is also a social network with large databases of knowledge attached, much of which is not otherwise available to offline Circassians (and others) and which is regularly being brought to use in the ongoing Circassian revival. This illustrates how the Internet can function as an integrating medium for both mobilisation and memorialisation. 
The Internet has become a space for the reproduction of cultural traditions and history - representations of Circassian culture - that is also a tool that can reach out to large audiences, including beyond the Caucasus, to other Caucasians or to the Circassians that reside as geographically dispersed groups in many different states around the world.

Circassia (and the Circassians) was recorded in many of the early printed representations of the Russian nation and empire in the mid-nineteenth century as a wild frontier region in need of civilisation by an expanding modern European empire. The competition with Great Britain, however, generated competing printed representations of Circassia in the West - albeit still largely in an Orientalist manner, as described by Edward Said. These representations described a nation with a number of prerequisites for becoming a modern nation-state. These competing versions of Circassian history are now presented as documentation, recycled and reproduced on the Internet in a number of different forms.

The Internet is an arena for the return of geography (Hooson 1994, 134), for the return of history (Henze and Enders Wimbush), for contested spaces (Smith 1999, 50) and for contested histories (Smith 1999, 33) - all post-1991 statements that are of relevance to the situation in homeland Circassia in the North Caucasus as well as the diaspora. This is also relevant for virtual Circassia as found on the Internet today. To a casual viewer, this might appear as scattered and dissimilar, but nevertheless jointly constitutes a form of virtual territorial identity.

'iCircassia' is represented by a strongly increased presentation of extremely visible elements of a thus far often more uncertain or distant homeland. Suddenly there is an archive, a museum, a library - always available, always open, always accessible - and, perhaps most importantly, constantly made relevant by the news items regularly posted on the front page. How all of these efforts will affect the future production and reproduction of Circassian identity remains to be seen, although the distance between the homeland and diaspora Circassians appears to be slowly diminishing.

The Internet has increased Circassian visibility through a 
combination of different forms of media (electronic, digital, texts, images, films etc.), including interactive options for (transnational) communication. Jointly, all these new forms of media, with easier access for both users and producers compared to previously, could be labelled as a new - and additional - language of nationhood for the Circassians. ${ }^{45}$

"Virtual nations are patterned on existing national, yet with different modes of interaction and representation" (Schaefer 2006). 'iCircassia' is an imagined community that contains a number of the same features that most modern nations and ethnic groups - in spite of diverging power implications - and 'iCircassia' still is a relatively new accomplishment of transnational endeavours among the geographically scattered Circassians. Precisely how 'iCircassia' should be represented is a constantly ongoing discussion and a dynamic process including an everincreasing number of people.

\section{BIBLIOGRAPHY}

BELLER, M. and J. Leerssen (eds.). 2007. Imagology. Amsterdam and New York: Rodopi Publishers.

BESLENEY, Z.A. 2014. The Circassian Diaspora in Turkey: A Political History. London and New York: Routledge.

BRINKERHOFF, J. M. 2009. Digital Diasporas: Identity and Transnational Engagement. New York: Cambridge University Press.

COHEN, D. J. and Roy Rosenzweig. 2006. Digital History. Philadelphia: University of Pennsylvania University Press.

CONVERSI, D. 2012. 'Irresponsible Radicalisation: Diasporas, Globalisation and Long-Distance Nationalism in the Digital Age'. Journal of Ethnic and Migration Studies Vol. 38, No. 9, November 2012.

ERIKSEN, Thomas Hylland. 2007. 'Nationalism and the Internet'. Nations and Nationalism, Vol. 13 (1), 2007.

EVERETT, A. 2009. Digital Diaspora: A Race of Cyberspace. New York: Suny Press.

FORTE, M. 2006. 'Amerindian@Caribbean: Internet Indigeneity in the Electronic Generation of Carib and Taino Identitites'. In Native on the Net:

${ }^{45}$ Inspired by Camilla Gibb (2006). 
Indigenous and Diasporic Peoples in the Virtual Age, Kyra Landzelius (ed.). New York and Abingdon: Routledge.

GIBB, C. 2006. 'Deterritorialized People in Hyperspace', in Native on the Net. Kyra Landzelius (ed.). London and New York: Routledge.

GLADWELL, M. 2000. The Tipping Point: How Little Things can Make a Big Difference. New York: Little, Brown and Company.

HANSEN, L. F. 2003. 'Demografiske ændringer i Nordkaukasus'. In Korsvej og minefelt - kultur og konflikt i Kaukasus. Ib Faurby and MärtaLisa Magnusson (eds.). Århus: Systime Academic.

HENZE, P. B. and S. Enders Wimbush: 'The Return of History'. www.circassianworld.com/pdf/Return_History.

HIMPELE, J. D. 2008. Circuits of Culture: Media, Politics, and Indigenous Identity in the Andes. Minneapolis and London: University of Minnesota Press.

HOOSON, D. 1994. Geography and National Identity. Oxford: Blackwell.

JENKINS, H. 2009. 'If it doesn't spread, it's dead (part five): Communities of users'. http://www.henryjenkins.org/2009/02/if_ it_doesnt_spread_its_dead_p_4.html (20-02-2009).

KAYA, A. 2014. 'The Circassian Diaspora In and Outside Turkey. Problems of Post-Communism, Vol. 61, Issue 4.

KRAIDY, M. M. and S. Mourad. 2010. 'Hypermedia Space and Global Communication Studies: Lessons from the Middle East'. Global Media Journal, Vol. 9, Issue 16, Spring 2010.

MANOVICH, L. 2001. The Language of New Media. Cambridge Mass: MIT Press.

LANGE, P. G. 2009. 'Videos of Affinity on YouTube'. In The YouTube Reader. Pelle Snickars and Patrick Vonderau (eds.). Stockholm: Mediahistoriskt Arkiv 12.

RICHMOND, W. 2013. The Circassian Genocide. New Brunswick: Rutgers University Press.

SAID, E. 1978/1995. Orientalism. London: Penguin Books.

SCHAEFER, J. P. 2006. 'Discussion lists and public policy on iGhana'. In Native on the Net. Kyra Landzelius (ed.). London and New York: Routledge.

SHAMI, S. 1998. 'Circassian Encounters: The Self as Other and the Production of the Homeland in the North Caucasus'. Development and Change, Vol. 29, Issue 4. October 1998.

SMITH, L. T. 1999. Decolonizing Methodologies. London and New York: Zed Books Ltd./ Dunedin: University of Otago Press.

SNICKARS, P. 2009. 'The Archival Cloud'. In The YouTube Reader. Pelle 
Snickars and Patrick Vonderau (eds.). Stockholm: Mediahistoriskt Arkiv 12.

TURNER, F. 2006. From Counterculture to Cyberculture. Chicago and London: University of Chicago Press.

VALTYSSON, B. 2012. 'Facebook as a Digital Public Sphere: Processes of Colonization and Emancipation'. Triple C Vol. 10 (1) 2012.

WAHLBERG, M. 2009. 'YouTube Commemoration: Private Grief and Communal Consoloation'. In The YouTube Reader. Pelle Snickars and Patrick Vonderau (eds.). Stockholm: Mediahistoriskt Arkiv 12.

WALLSTEN, K. 2010. "Yes We Can": How Online Viewership, Blog Discussion, Campaign Statements, and Mainstream Media Coverage Produced a Viral Video Phenomenon'. Journal of Infomation Technology and Politics, Vol. 7, Issue 2-3. 2010.

VAN DIJCK, J. 2007. Mediated Memories in the Digital Age. Stanford CA: Stanford University Press.

ZHEMUKHOV, S. 2012. 'The Birth of Circassian Nationalism'. Nationalities Papers, Vol. 40, No. 4, July 2012. 